\title{
Effect of Social Infrastructure Investment on Economic Growth and Inequality in South
} Africa: A SEM Approach

\author{
Itumeleng More and Goodness C. Aye ${ }^{\mathrm{a}}$ \\ Department of Economics \\ University of Pretoria \\ Pretoria \\ South Africa
}

\begin{abstract}
This paper investigates the effect of social infrastructure on economic growth and inequality in South Africa using a SEM approach. We use growth as the mediating variable while controlling for production factors, urbanisation and globalisation. Results show a positive and significant relationship between education expenditure and growth. However there is a negative but insignificant relationship between health expenditure and growth. Furthermore, results indicate a negative but insignificant relationship between education and inequality and a significant negative relationship between health and inequality. Consistent with the Kuznets theory, we find a positive and significant relationship between growth and inequality in South Africa.
\end{abstract}

Keywords: Education; health; growth; inequality; SEM

\section{Introduction}

This paper examines the effect of social infrastructure on economic growth and inequality in South Africa. Social infrastructure refers to infrastructure that caters for social services such as prisons, hospitals, public schools etc (Fedderke and Garlick, 2008). During the apartheid era a lot of government spending went towards infrastructure that served the white community, this left very little expenditure for the social infrastructure of the black majority and other races.

a Corresponding Author's Email: goodness.aye@gmail.com 
These choices promoted poverty and broadened inequality. 21 years into democracy South Africa is still dealing with the consequences of poor fiscal choices made in the past. Income and gender inequality are very prominent in our modern society. In most cases men still earn more than women and rates differ between races for the same job (Bhorat and Van Der Westhuizen, 2012). South Africa is taking note of women but at a very slow pace.

South Africa is known to be a very unequal country, even post-apartheid. The World Bank's Gini index indicates that just after apartheid inequality decreased from 59.3 in 1993 to 56.6 in 1995. However this was short lived as in the year 2000 the Gini index number had increased to 57.8 and 65 in 2011(World Bank, 2015). Inequality can lead to conflicts between citizens and the authorities. Continued conflicts within a country decrease the quality of democracy and can potentially scare away investors which will negatively affect economic growth (Bermeo, 2009).

Since 1994 economic growth has been one of the top priorities in South Africa. Post apartheid, South Africa reintegrated into the world economy and economic sanctions were removed. This led to the positive economic performance between 1994 (3\%) and 1997(3\%) (World Bank, 2015). Since the introduction of democracy we have experienced fluctuations in economic growth. In 1994 GDP growth rate was at an impressive 3\% an increase of more than one percentage point from 1993. GDP peaked in the period 2005-2007 with rates 5\%, $6 \%$ and 5\% respectively. From 2007 to 2014 GDP has declined substantially. The steep decline in 2009 ($2 \%$ ) can be explained by the global recession (World Bank, 2015). The increment seen in 2010 (3\%) (World Bank) is due to the world cup hosted on our homeland. Economic growth does not solve the issue of inequality if the growth continues to be unequally distributed. Therefore, this study considers the effect of infrastructure on economic growth as well as its distributional impact.

The specific objectives of the study are: first to investigate the effect of education and health expenditures on economic growth; second to examine the effect of education and health expenditure on inequality. The first expectation is that investment in social infrastructure (education and health expenditure) should increase economic growth. Expectation 2 is that investment in education and health is inversely related to the Gini index, thus the more investment in education and health care, the lower inequality should be. 
Past literature including but not limited to Chandra and Thompson (2000), Röller and Waverman (2001), Perkins et al. (2005) and Pradhan and Bagchi (2012) put a lot of emphasis on economic infrastructure. This paper contributes to literature as there have not been many studies that focus on the impact of social infrastructure on economic growth and inequality in South Africa. In the second quarter of 2015 South Africa experienced a contraction with GDP falling to $-1.3 \%$ (Stats SA, 2015). Since South Africa is failing to reach growth targets, it has become important to investigate factors whose impacts on the economy have been overlooked, for example social infrastructure. Social infrastructure encourages more efficient use of physical infrastructure and human resources thus leading to increased economic growth (Hall and Jones, 1999). Furthermore Hall and Jones (1999) argue that international differences in levels of output per worker are influenced by differences in human capital, social and physical infrastructure. Countries such as China have improved their macroeconomic environment, investments, exports and employment over 25 years due to a huge investment in physical and social infrastructure (Straub et al, 2008). The improvements seen in these other countries are exemplary of the results to be expected if South Africa starts to invest more in social infrastructure.

In this study we use the structural equation modeling approach. The advantage of structural equation modeling over traditional regression analysis is that it explicitly models measurement errors and can estimate parameters with full information maximum likelihood (FIML), which provides consistent and asymptotically efficient estimates (Chang et al., 2009).

The rest of the paper is organized as follows: section two reviews empirical literature as it relates to this paper. In section three a description of the methodology and theoretical framework is given. Results are presented in section four while section five concludes.

\section{Literature Review}

A lot of research has been done globally on the role of infrastructure in economic growth, although some results were mixed or even negative among the growth studies using measures of public capital stocks or infrastructure spending flows, most of them found positive long-run effects of infrastructure on growth (Straub, 2007).

Kularatne (2006) investigate the effect of economic and social infrastructure on the economy in South Africa. The study created indices for social infrastructure using schooling infrastructure data and economic infrastructure using roads and railways data. The author 
makes use of the Pesaran et al. $(1996,2001)$ F-statistics to determine the direction of association between variables. To test for a long run relationship they first estimate an error correction specification, followed by computing the standard F-statistic for the joint significance of variables. Critical values are tabulated by Pesaran et al $(1996,2001)$ proving a lower and upper bound value to the test statistic. If the test statistic exceeds the upper bound, reject the null hypothesis thus the variables are significantly different from zero and a long run relationship exists and vice versa should the test statistic be lower than the lower bound. To estimate the relationship between the social and economic infrastructure on economic growth, the Johansen estimation technique and Vector Error Correction Model (VECM) are also used. Threshold Autoregressive Estimation (TAR) is further used to test for non-linearity between investment in economic and social infrastructure and economic growth. Results showed that expenditure on education and hospitals led to a more equipped labour force while expenditure in roads and railways led to an increase in private investment rates. The study concludes that a more equipped labour force is more productive and an increase in private investment rates stimulates the economy thus social and economic infrastructures have a positive effect on the economy.

Gnade (2013) examined the effect of basic infrastructure delivery on welfare in rural and urban municipalities in South Africa. The objective of the paper was examine whether delivery of basic infrastructure impacts growth and development in a positive and significant way and further compare the impact that this delivery has on rural and urban areas in South Africa. The study used comparative data from 1996-2012 to create indicators for inequality, growth and poverty whilst taking anecdotal evidence into account. The author calculated an index of stock of basic infrastructure, namely sanitation, water and electricity, in multiple municipalities using data on the number of households with hygienic toilets, the provision of water in households above RDP-level and the households that had electricity. Various statistical techniques (not specified) were used for analysis. Results indicated that investment in basic infrastructure would have a positive and significant impact on inequality, poverty and growth. The impact that Infrastructure investment had on inequality, poverty and growth was higher in urban areas.

Wang (2007) developed a theoretical model to examine how the political power and productivity distribution would determine the formation and dynamics of the different coalition structures among different social groups and how these endogenous social infrastructures affect the society's macroeconomic performance in terms of growth and consumption distribution using China as a case study. He based his model on Benhabib and Rustichin (1996). He also 
makes use of the Cobb-Douglass production function to show how any changes in the productivity distribution among different social groups might cause a drastic change in social structure which in turn can determine consumption distribution. The different coalitions here are interpreted as different social infrastructures that reflect certain important features of different political institutions. The model considers an economy with three infinite players or agents, each of whom represents a social group e.g. (upper, middle and lower class).

The main findings Wang's (2007) study are that coalitions are more likely to be formed between social groups with relatively equal political powers and labour productivity distribution will lead to more coalitions and higher economic growth rate. Any change in the distribution of labour productivities like a change in technology could result in a drastic change in the coalition structure and the macroeconomic performance. In a non-democracy the ruling class might choose to extend some political rights to other social groups to exploit them, which could lead to growth maximization. The social coalition structure evolves endogenously as the political power distribution changes; therefore the persistence of political power distribution eventually translates into the persistence of economic growth rate and consumption inequality.

Sahoo et al (2012) investigated the role of physical and social infrastructure in economic growth in India after controlling for variables such as trade, labour force and investment. They made use of data in the period 1970 to 2006 and analysed it using Two-Stage Least Squares (TSLS) and Dynamic Ordinary Least Squares (DOLS) techniques. Unlike past literature, the focus of this study is not limited to the stock of physical infrastructure, it also analyses the impact of human capital on output on the basis of endogenous growth theories. The study develops a composite index of stock of leading physical infrastructure indicators to examine the impact of infrastructure development on output. The study acknowledges the nonstationarity of data and takes care of issues of reverse causation and a spurious correlation. This study complements existing studies, which focus mainly on developed economies, by evaluating the role of infrastructure for the case of a developing economy. The results of the study imply that physical and social infrastructures have a significant positive impact on output apart from gross domestic capital formation and international trade. Further, the causality analysis revealed unidirectional causality from infrastructure development and human capital to output growth in India, which supports the results of the study. 
Demurger (2001) studied the impact of infrastructure in growth performance in 24 provinces of China and concluded that infrastructure endowment together with reforms openness and geographical location impact significantly on economic growth in those provinces. The key findings of this investigation are that infrastructure development and human capital such as expenditure on education and have a significant positive contribution to growth. Furthermore they found that infrastructure development has more significant contribution to growth than both private and public investment, but infrastructure stock, labour force, public and private investment also play an important role in economic growth in China. China is a good example that proves that in order to sustainably grow the economy in a developing country, you need an economic policy that that will improve the physical infrastructure and human capital, hence China has been heavily spending a lot of their direct budget investment from fiscal resources, borrowed money and market based financing on both physical and social infrastructure development since the early nineties.

Chatterjee (2005) and Strub et al (2008) state that China's sustained high economic growth and increased competitiveness has been underpinned by a massive development of physical infrastructure.

Hall and Jones (1999) found that social infrastructure such as education, health and housing are important utilities that that help nations to better use the physical infrastructure and human resources, which in turn lead to higher economic growth and improving quality of life.

Fedderke and Garlick (2008) provide a broad overview of the relationship between infrastructure and growth in the context of South Africa. The study develops theoretical framework in which to analyse this relationship. Five channels through which infrastructure may affect growth are identified : as a factor of production, a complement to other factors of production, a stimulus to factor accumulation, a stimulus to aggregate demand and a tool of industrial policy. The paper develops a framework to evaluate this empirical relationship, which explores the implications of different definitions and measures of infrastructure and of potential data and estimation challenges. The empirical literature on South Africa is then assessed against this framework. The paper finds a robust positive relationship between infrastructure and economic growth. Furthermore findings imply that economic output is driven by aggregate infrastructure stock and investment, infrastructure impacts output via rising exports, increasing private sector investment and improved productivity. 
Perkins et al (2005), emphasize, different types of infrastructure may be particularly beneficial for growth at different times and under different circumstances. Finally, the relationship between infrastructure maintenance and economic growth remains almost entirely unknown, both internationally and in South Africa (Kessides, 1993), and this issue requires considerable attention in order to develop a comprehensive understanding of the infrastructure-growth relationship.

Calderón and Servén (2010) analysed the linkages between infrastructure and economic development in sub-Saharan Africa (SSA). Results based on a large panel data for 136 countries, show that infrastructure development is associated with both higher growth and lower inequality. They also found that while infrastructure made a large contribution to reducing inequality in East and South Asia, the impact was relatively modest in SSA due to poor quality of infrastructure. Ncube (2010) presents arguments on the relationship between infrastructure investments and economic growth in Africa and found that, in the literature, the causal nexus between infrastructure capital and economic growth and development, in general, has been ambiguous. More overview of studies on infrastructure and economic growth in Africa is provided in Ajakaiye and Ncube (2010).

\section{Methodology}

\subsection{Theoretical framework}

\subsubsection{Determinants of economic growth}

The Solow (1956) model suggests that output (Y) is a function of capital (K) and labour (L) therefore $\quad \mathrm{Y}=\mathrm{f}(\mathrm{K}, \mathrm{L})$

Spending more on social infrastructures induces more literacy, better health and manpower skill, which leads to higher productivity and growth (Sahoo, et al., 2012). Since the objective of this paper is to examine the effect of social infrastructure on economic growth we add social infrastructure (SI) as an additional variable. Our production function is now;

$$
\mathrm{Y}=\mathrm{f}(\mathrm{K}, \mathrm{L}, \mathrm{SI})
$$

In this paper social infrastructure is measured by education and health expenditure which is denoted by EDUEXP and HEXP respectively. Capital will be measured by gross domestic 
capital formation (GDCF), labour will be measured by labour force (LF) and output is measured by GNI per capita. We now replace SI, K and L with their proxies;

$$
\mathrm{Y}=\mathrm{f}(\mathrm{GDCF}, \mathrm{LF}, \mathrm{EDUEXP}, \mathrm{HEXP})
$$

Endogenous growth theory (Grossman and Helpman 1990; Barro and Sala-i-Martin 1995) and Trade theories (Krueger 1975; Bhagwati 1988) suggest that through increasing labour productivity, generating greater capacity of utilization, bringing more technological progress and opening up more employment opportunities, international trade plays an essential role in sustaining economic growth and increasing the total welfare of a nation. In-line with these studies trade openness $(\mathrm{T})$ can be added to the production function therefore our final production function is;

$$
\mathrm{Y}=\mathrm{f}(\mathrm{GDCF}, \mathrm{LFPR}, \mathrm{EDUEXP}, \mathrm{HEXP}, \mathrm{T})
$$

Trade openness is measured as the sum of imports and exports as a percentage of GDP (World Bank, 2015).

\subsubsection{Determinants of inequality}

Income and consumption are the monetary instruments commonly used to measure inequality. A Gini coefficient, through the analyses of the statistical distribution of either consumption or income, is calculated from a Lorenz curve to indicate inequality within a country (Todaro and Smith, 2009). The Gini coefficient is the international standard for measuring the distribution of income and wealth within a country. It essentially measures the gap between the poor and rich in terms of wealth and income. There are different ways to weight income and thus the outcome of the Gini coefficient calculation is influenced by the weighting method used.

Income inequality has been associated with variables such as education inequality, economic development, population growth and globalization (Ospina, 2010).

Research on the relationship between education and income inequality has produced mixed results. The bulk of studies found that income inequality and a countries average educational attainment had a negative relationship, (De Gregorio and Lee, 2002; Park, 1996; Psacharopoulos, et al, 1995; Ram, 1984). Deininger and Squire (1998) found that educational expenditures and inequality have a positive relationship. In contrast, Huber et al (2004) found that education expenditure has a negative impact on inequality. Barro (1999) investigated effect of educational attainment on inequality; he found a negative relationship for primary education attainment, but a positive relationship for higher education attainment. Checchi (2000) stated 
if we account for the distribution of educational attainment, the relationship between attainment and income inequality was actually U-shaped. These studies show that there exist a significant relationship between education and inequality. Educational variables to be included in the model are secondary and tertiary enrolment and the log of education expenditure. We expect educational attainment to reduce inequality.

Kuznets (1955) investigated the relationship between economic development and income inequality. He found a U-shaped curve; at lower levels of development, increased economic development is associated with increased inequality until a minimum point where increased development is now associated with decreasing inequality. Since South Africa is at medium levels of development we expect a positive relationship between economic development and income inequality. Hence, the GDP per capita is used in the current study as a measure of economic development.

Growth in population under the ages of 15 and aged population (above 65) are expected to increase inequality. Excess supply of unskilled young workers depresses lower incomes and increases wage differentials (Alderson and Nielsen, 1999). In many cases aged population is not productive and does not save thus has little income to transfer to the next generation (Deaton et al, 1997).

Boschi (1987) found that growth in the urban population contributes to growth in the middle class and thus more employment. Ospina reports that the proportion of labour force in agriculture has a positive relation to inequality. As labour shifts from agriculture to urban sector, low paid rural jobs become less significant and inequality should decrease. The above imply that urbanization affects income distribution. Population is therefore included as a variable in the inequality equation.

Indicators for globalization include openness and foreign investment income. In a sample of 80 countries over 40 years, Kraay et al (2002) found that open economies had less inequality. In contrast, Barro (2000) concludes that openness to trade is associated with increased inequality. Rudra (2004) found that openness has a severe impact on income inequality in poorer countries and that only education expenditure can mitigate this effect while spending on social security, health and welfare do not. This justifies the inclusion of trade openness in the inequality equation. 
Social and economic inequality is detrimental to the health of any society (Deogaonkar, 2004). Health outcome indicators (mortality, morbidity and life expectancy) are directly affected by the standards of living of a population. Furthermore, it is not the absolute deprivation of income that matters but the relative distribution of income (Wilkison, 1992). In a study by Kennedy et al (1996), income inequality was defined as the part of income that needs to be redistributed from the rich to the poor to achieve economic equality and was measured by the Robin Hood Index. A $1 \%$ increase in income inequality led to 21.7 excess deaths per 100000 people. Lastly, Huber et al (2004) found that health expenditure has a negative impact on inequality and their results show the significant relationship between income inequality and the health of a population.

Using the above literature the inequality model is specified as follows:

Gini=f (Eduexp, Hexp, GDP, POP15, POP65, POPUBAN, T, FDI)

where; Gini is the Gini index, GDP is gross domestic product per capita, pop15 is population aged 15 and younger as a percentage of total population,pop65 is population aged 65 and older as a percentage of total population, popurban is Urban population which refers to people living in urban areas as defined by national statistical offices, trade is the sum of exports and imports of goods and services measured as a share of gross domestic product. FDI is foreign direct investment and finally hexp is health expenditure.

\subsubsection{Estimation method}

There is possibility of endogeniety in the relationship we set out to examine. Therefore, Equations (4) and (5) are estimated using the structural equation (SEM) approach. Different forms of the models are fitted and the best is selected for discussion. By using a SEM approach, we overcome the problems of traditional regression approach. On one hand, regression analys is does not control measurement errors and can only deal with one dependent variable at a time. On the other hand, SEM not only controls the measurement errors but also is able to handle several dependent variables. With respect to the independent variables, SEM allows several observable variables as indicators of the theoretical constructs without causing multicollinearity problems. Further, traditional regression deals with observable variables but not latent constructs. It assumes the observable proxies to be the exact measures of the theoretical constructs, though this may not be true due to measurement errors. In empirical 
research, the assumptions of regression analysis can easily be violated, while the normality distribution required by the maximum likelihood estimation method in structural equation modeling can be met by a normal score transformation (Chang et al., 2009).

\subsection{Data}

Infrastructure is broadly grouped as economic and social infrastructure. Economic infrastructure consists of electricity, sanitation, water supply and transport facilities, while social infrastructure conventionally includes educational and health facilities some authors add recreational activities and government housing such as RDP's.

Infrastructure can be analysed as a stock or flow variable. A flow is measured with reference to a period of time thus the magnitude of its impact can be measured over a period of time. A stock on the other hand is measured at a particular point of time hence it shows the quantity of a variable for a specific date. When measuring infrastructure as a stock we compare it to aggregate output (GDP) as stocks and GDP are cumulative measures, whilst when using flows we would compare it to GDP growth (Fedderke and Garlick, 2008). In this paper we will use GDP per capita reported by the World Bank.

Infrastructure can be measured financially or physically. Financial measures look into the expenditure invested in infrastructure. Physical measures vary depending on the infrastructure being measured; number of schools built in a specific year, the length of repaired roads etc. In this paper we will use financial measures of infrastructure. These are education and health expenditure abstracted from easy data.

Capital and labour force data were extracted from easy data. Primary enrolment, GDP, population, FDI and trade data were extracted from the World Bank.

The Gini index used in this paper was abstracted from The World Bank. The World Bank weights income by household size and calculates the share held by individuals rather than households. Data on the Gini coefficient is poorly reported thus this paper interpolates for missing data. This paper employs spline interpolation which is a generalisation of linear interpolation. Spline interpolation incurs a smaller error than linear interpolation and the interpolant is smoother. Interpolation was done through Eviews. The resulting Gini coefficient after interpolation is shown below in Figure 1. 
A complete data set of the Gini index was then created and used in the regression analyses that tests hypothesis two: investment in education and health is inversely related to the Gini index. Data on Education and health expenditure was extracted from easy data.

Also given that the data is time series, the paper examines the unit root properties to avoid spurious regression. The Augmented Dickey-fuller and unit root tests are used to test for stationarity with a null hypothesis of a unit root (i.e. non-stationarity). In the case of nonstationarity, all distributions are non-standard, thus standard $t$ and $\mathrm{f}$ tests cannot be used. This is remedied by computing the first difference.

\section{Results}

Augmented Dickey Fuller test and the Phillip Peron test were used to check for stationarity. The results are presented in Table 1. The null hypothesis of unit root could not be rejected for all variables except the Gini index. This means that all the variables are non-stationary, only Gini index is stationary. However, the tests on first difference of these non-stationary series show that they do not contain unit roots. Thus the null hypothesis is rejected for first differe nced series. Hence all series excluding Gini index have been differenced once before estimating the SEM model.

We estimated three different models starting first with the model that examines only the effect of the main variables: education expenditure and health expenditure, in relation to the dependent variables, while controlling for other variables. The estimated models as shown in Table 2 are in general of good fit given the various diagnostic statistics. However, based on the Akaike information Criterion (AIC) and Schwartz information criterion (SIC), model 2 is selected for discussion. Focusing first on the growth equation whose results are reported in the second panel, Model 2 shows a positive relationship between education expenditure and economic growth which is in-line with expectations. The coefficient of education is signific ant at $10 \%$. In contrast model 2 shows a negative relationship between health expenditure and economic growth. We expected a positive relationship between health expenditure and growth. All three models imply that health expenditure effect is not significant, implying that health infrastructure does not have much impact on economic growth in South Africa. 
The results for the effect of the main variables education and health expenditure on Gini index while controlling for other variables are reported in the upper panel of Table 2. Model 2 shows a negative relationship between education expenditure and inequality, which is in line with expectations. This implies that an increase in education expenditure decreases inequality. However it is noted that the impact of education expenditure on inequality is according to the results insignificant. Model 2 also shows a negative and significant relationship between health expenditure and inequality which implies that an increase in health expenditure leads to a decrease in inequality. This again is consistent with our a priori expectations. All three regressions show that health expenditure is significant.

It is important to note that GDP in the inequality equation is consistently positive and significant at $1 \%$. This implies that an increase in growth leads to an increase in equality. This is consistent with the Kuznets theory which founds a U-shaped curve at lower levels of development implying that an increased economic development is associated with increased inequality until a minimum point where increased development is now associated with decreasing inequality.

In Table 3, we report the direct, indirect and total effects of health and education expenditure on growth and inequality. We observe that the indirect effect of education on inequality which is positive appear to dominate the direct effect which is negative, thus resulting in a positive total effect. However, for health, both the direct and indirect effect has negative relationship with inequality and hence a total negative effect. The direct and total effects are similar for the growth equation since the variables did not enter into the growth equation indirectly.

\section{Conclusion and Policy Implications}

In this study we investigated the role of social infrastructure in economic growth and inequality in South Africa after controlling for other important variables such as capital, labour force and trade using the structural equation modelling technique (SEM) for the period 1994-2013. Unlike most papers that only focus on economic infrastructure, this paper looks into social 
infrastructure proxied by education and health expenditure and thus contributes to literature as there have not been studies that focus on the impact of social infrastructure on economic growth and inequality in South Africa. We found that in the context of South Africa, education has a positive effect on economic growth and a negative effect on inequality as expected. While the effect on growth is significant, the effect on inequality is not significant. With respect to health expenditure, we found the effect is negative on economic growth but not significant while the effect is negative and significant on inequality. Our findings have important policy implications. First, it should be noted that allocation of expenditure does not guarantee efficient use of expenditure. Furthermore, building more education and health infrastructure may not translate into better quality health and education services. Factors such as lack of implementation and corruption should not be ignored. For example education expenditure that favours schools where the elites children, particular race or gender will definitely leave inequality unaddressed if not worsened. Expenditure on schooling increases economic growth by improving the quality of the labour force. The quality of the labour force can only improve if the quality of education improves. Although the education budget has increased over the years, South Africa is still ranked amongst the worst in maths and science education. The World Economic Forum (WEF) ranked South Africa last out of 148 countries for the quality of its maths and science education (2014). The WEF's Global Information Technology Report also ranked South Africa $146^{\text {th }}$ out of 148 countries, for overall quality of education. Moreover, the way in which health expenditure is allocated plays a role in the impact it will have on economic growth and inequality. If more hospitals are built but labour is not qualified to run the hospital then the hospitals will not be fruitful. South Africa is still an emerging economy with much gap in terms of skills. If many hospitals of low quality are built then these will do no good for the economy. If hospitals are still located far from the poor, the cost of accessing these hospitals remains a barrier, thus inequality is not addressed. Diminishing returns to scale should also be taken into account as increasing expenditure does not always solve the issue. In sum, corruption could have also affected the impact of infrastructure growth and inequality, among other things. Therefore, the importance of independent regulation agencies in ameliorating the consequences of corruption on infrastructural services cannot be overemphasized. 


\section{References}

Ajakaiye, O. and Ncube, M. (2010). Infrastructure and economic development in Africa: An Overview. Journal of African Economies, 19 (suppl 1), i3-i12.

Alderson, A. S. and Nielsen, F. (1999). Income inequality, development, and dependence: A reconsideration. American Sociological Review, 64, 606-631.

Barro, R. J. and X. Sala-i-Martin (1995). Economic growth. New York: McGraw-Hill.

Barro, R. J. (1999). Inequality, growth, and investment (NBER Working Paper No. W7038).

Cambridge, MA: National Bureau of Economic Research (NBER).

Barro, R. J. (2000). Inequality and growth in a panel of countries. Journal of Economic Growth, 5, 5-32.

Benhabib, J. and Rustichini, A. (1996). Social conflict and growth. Journal of Economic Growth, 1,125-142.

Bermeo, N. 2009. Does electoral democracy boost economic equality? Journal of Democracy, 20(4), 21-35.

Bhagawati, J. N. (1988). Export-Promoting trade strategies: issues and evidence. The World Bank Research Observer.

Bhorat, H. and Van Der Westhuizen, C (2012) Poverty, inequality and the nature of economic growth in South Africa. Dpru Working Paper 12/151.

Boschi, R. R. (1987) Social movements and the new political order in Brazil, in J. Wirth, E. S. Nunes, T. E. Bogenshield (Eds), State and Society in Brazil: Continuity and Change, Westview Press, Boulder, CO, pp 182-192.Calderón, C. and Servén, L. (2010). Infrastructure and economic development in Sub-Saharan Africa. Journal of African Economies, 19 (suppl 1), i13-i87.

Chandra, A. and Thompson, E. (2000). Does public infrastructure affect economic activity?: Evidence from the rural interstate highway system - Regional Science and Urban Economics, 30(4), 457-490.

Chang, C., Lee, A.C. and Lee, C.F. (2009) Determinants of capital structure choice: A structural equation modeling approach. The Quarterly Review of Economics and Finance 49(2),197-213.

Chatterjee, S. (2005). Poverty Reduction Strategies: Lessons from the Asian and 
Pacific Region on Inclusive Development. Asian Development Review, 22, 12-44

Checchi, D. (2000). Does educational achievement help to explain income inequality?

(Working Paper No. 208). Helsinki: United Nations University, World Institute for Development Economics Research (WIDER).

Deaton, A., and C. Paxson (1997) The effects of economic and population growth on national saving and inequality. Demography 34:97-114.

De Gregorio, J., and Lee, J. (2002). Education and income inequality: New evidence from cross country data. The Review of Income and Wealth, 48, 395-416. Deininger, K., and Squire, L. (1998). A new dataset measuring income inequality. World Bank Economic Review, 10(3), 565-591.

Demurger, S. (2001). Infrastructure Development and Economic Growth: An Explanation for Regional Disparities in China? Journal of Comparative Economics, 29(1), 95-117.

Deogaonkar, M. (2004). Socio-economic inequality and its effect on healthcare delivery in India: Inequality and healthcare. Electronic Journal of Sociology, 8(1).

Fedderke, J. and Garlick, R. (2008) Infrastructure development and economic growth in South Africa: A review of the accumulated evidence. http://www.econrsa.org/system/files/publications/policy_papers/pp12.pdf

Gnade, H (2013). The effect of basic infrastructure delivery on welfare in rural and urban municipalities. http://www.econ3 x3.org/article/effect-basic-infrastructure-delivery-welfarerural-and-urban-municipalities.

Grossman, G. M. and Helpman, E. (1990). Comparative advantage and long-run growth. American Economic Review, 80(4), 796-815.

Hall, E. and Jones, C (1999). Why do some countries produce so much more output per worker than others? The Quarterly Journal of Economics, 114(1), 83-116.

Huber, E., Nielsen, F., Pribble, J. and Stephens, J. D. (2004). "Social spending and inequality in Latin America and the Caribbean." Paper delivered at the Meetings of the Society for the Advancement of Socio-Economics, Washington, D.C., July 8-11. 
Kennedy, B.P., Kawachi, I. and Prothrow-Stith, D. (1996). Income distribution and mortality: Cross sectional ecological study of Robin Hood Index in the United States. British Medical Journal, 312(7037),1004-7.

Kessides, C. (1993). The contributions of infrastructure to economic development : a review of experience and policy implications. World Bank discussion papers ; no. WDP 213. Washington, DC : The World Bank. http://documents.worldbank.org/curated/en/569671468764675127/The-contributions-ofinfrastructure-to-economic-development-a-review-of-experience-and-policy-implications.

Kraay, A. and Dollar, D. (2001). Growth is good for the poor. Policy Research Working Paper Series 2587, The World Bank. http://elibrary. worldbank.org/doi/pdf/10.1596/18139450-2587.

Krueger, A.O. (1975). The Benefits and Costs of Import Substitution in India: A Microeconomic Study, Minneapolis: University of Minnesota Press.Kularatne, C. (2006). Social and economic infrastructure impacts on economic growth in South Africa. TIPS, Development Policy Research Unit, Conference, The Birchwood Hotel and Conference Centre, Johannesburg, South Africa, 18-20 October, 2006.

Kuznets, S. (1955). Economic growth and income inequality. American Economic Review, 45, 1- 28. 28.

Ncube, M. (2010). Financing and managing infrastructure in africa. Journal of African Economies, 19(suppl 1), i114-i164.

Ospina, M. (2010) The Effect of Social Spending on Income Inequality: An Analysis for Latin American Countries. Universidad EAFIT. https://repository.eafit.edu.co/bitstream/handle/10784/573/20103\%20Monica\%20Ospina.pdf;jsessionid=587529ADA581ACACF272647637C7389D? sequen $\mathrm{ce}=1$

Park, K. (1996). Educational expansion and educational inequality on income distribution. Economics of Education Review, 15(1), 51-58. 
Perkins, P., Fedderke, J. and Luiz, J. (2005) An analysis of economic infrastructure investment in South Africa. South African Journal of Economics, 73(2), 211-228.

Pesaran, MH, Shin, Y and Smith, RJ. (1996). Testing for the existence of a long-run relationship, DAE Working Paper no. 9622, Department of Applied Economics, University of Cambridge.

Pesaran, MH, Shin, Y, and Smith R. (2001). Bounds testing approaches to the analysis of level relationships, Journal of Applied Econometrics, 16: 289--326.

Pradhan,P and Bagchi, P(2012) Effect of transportation infrastructure on economic growth in India: The VECM approach.

Psacharopoulos, G., Morley, S., Fiszbein, A., Lee, H. and Wood, W. C. (1995). Poverty and income inequality in Latin America during the 1980s. The Review of Income and Wealth, 41(3), 245-264.

Ram, R. (1984). Population increase, economic growth, educational inequality, and income distribution: Some recent evidence. Journal of Development Economics, 14, 419-428.

Röller, L.H. and Waverman, .L (2001)

Telecommunications infrastructure and economic development: A simultaneous approach American economic review, 91(4), 909-923

Rudra, N. (2004). "Openness, Welfare Spending and Inequality in the Developing World," International Studies Quarterly. Vol. 48. 48, 683-709.

Sahoo, P., Dash, R.K. and Nataraj, G. (2012) China's growth story: the role of physical and social infrastructure - Journal of Economic Development, 37(1), 53-75.

Solow, R.M. (1956). A contribution to the theory of economic growth. Quarterly Journal of Economics, 70.1:65-94.

Stats SA (Statistics South Africa) (2015). South Africa's economy narrowly avoids recession. 
www.statssa.gov.za/?p=5861.

Strub, S., C. Vellutin, and M. Warlters (2008). Infrastructure and Economic Growth in East Asia. The World Bank Policy Research, Working Paper, 4589.

http://elibrary.worldbank.org/doi/abs/10.1596/1813-9450-4589.

Straub, S., C. Vellutini, and M. Warlters. 2008. Infrastructure and Economic Growth in East Asia. Policy Research Working Paper 4589, World Bank, Washington, DC.

Straub, S. (2007) "Infrastructure and development: A critical appraisal of the macro-level literature" Discussion paper series number 178. The University of Edinburgh

Todaro, M, and Smith S (2009) Economic Development Addison-Wesley, London, - Chapter 3 -Classic Theories of Economic Development

Wang,Y (2007) A theory of social infrastructure and economic development. Department of Economics, University of Chicago.

World Bank (2015) GINI index (World Bank estimate). http://data.worldbank.org

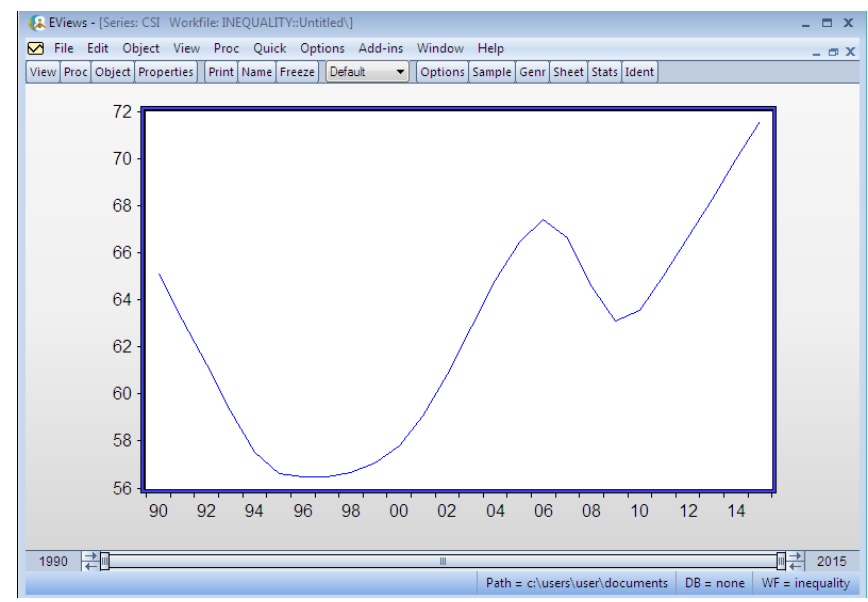

Figure 1: shows that inequality has increased over time 
Table 1: Unit root results for all variables

\begin{tabular}{|c|c|c|c|c|c|c|}
\hline \multirow[b]{2}{*}{ Variables } & \multicolumn{2}{|l|}{$\begin{array}{l}\text { Level } \\
\text { ADF }\end{array}$} & \multicolumn{2}{|c|}{$\begin{array}{l}\text { First difference } \\
\text { ADF }\end{array}$} & \multicolumn{2}{|c|}{$\begin{array}{l}\text { First difference } \\
\text { PP }\end{array}$} \\
\hline & Constant & $\begin{array}{l}\text { Constant } \\
\text { and } \\
\text { trend }\end{array}$ & Constant & $\begin{array}{l}\text { Constant } \\
\text { and } \\
\text { trend }\end{array}$ & Constant & $\begin{array}{l}\text { Constant } \\
\text { and trend }\end{array}$ \\
\hline GDP & 0.121 & -1.439 & $-2.957 *$ & -2.892 & -1.731 & -1.706 \\
\hline Education & -2.348 & -2.599 & $-3.302 * *$ & $-3.450 *$ & $-3.293 * *$ & $-3.457 *$ \\
\hline Health & 1.145 & -1.328 & $-3.547 * *$ & $-3.592 *$ & $-3.545 * *$ & $-3.565^{*}$ \\
\hline \multirow[t]{2}{*}{ Openness } & -2.033 & -3.167 & - & - & $-7.300 * * *$ & $-6.748 * * *$ \\
\hline & & & $4.729 * * *$ & $4.599 * * *$ & & \\
\hline Labour & -2.181 & -2.204 & $-2.982 *$ & -3.001 & $-2.833 *$ & -2.748 \\
\hline Capital & -1.205 & -1.646 & $-3.815 * *$ & $-3.796 * *$ & $-3.828 * *$ & $-3.806 * *$ \\
\hline Gini & -0.687 & $-4.227 * *$ & $-3577 * *$ & $-4.582 * *$ & -1.83 & -1.782 \\
\hline \multirow[t]{2}{*}{ FDI } & -3.643 & -3.33 & - & $-4.77 * * *$ & - & - \\
\hline & & & $5.019 * * *$ & & $24.937 * * *$ & $23.888 * * *$ \\
\hline \multirow[t]{2}{*}{ Population_urban } & -2.566 & -3.207 & - & - & $-17.11 * * *$ & - \\
\hline & & & $6.896 * * *$ & $6.691 * * *$ & & $17.829 * * *$ \\
\hline \multirow[t]{2}{*}{ Population_15 } & 0.377 & -3.233 & - & - & $-8.051 * * *$ & $-8.269 * * *$ \\
\hline & & & $7.645 * * *$ & $7.532 * * *$ & & \\
\hline
\end{tabular}




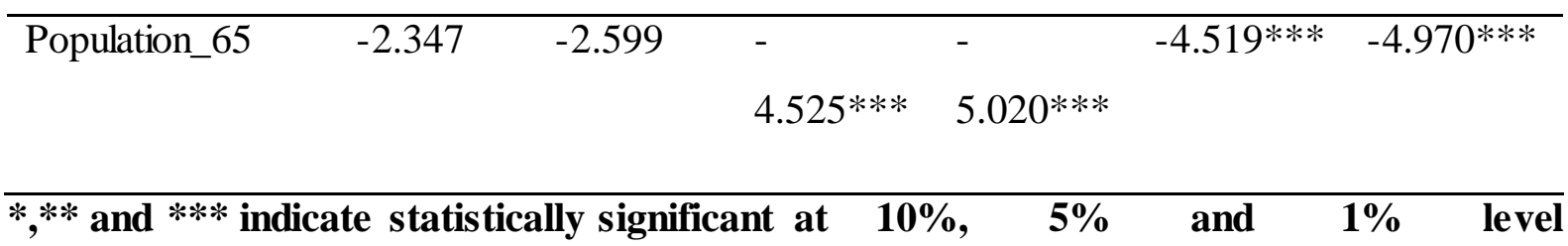

Table 2: Estimates of the structural equation modelling

\begin{tabular}{|c|c|c|c|}
\hline & Model 1 & Model 2 & Model 3 \\
\hline \multicolumn{4}{|l|}{ GINI Equation: } \\
\hline \multirow[t]{2}{*}{ GDP } & $0.147^{* *}(0.000)$ & $0.195^{* *}$ & $0.150^{* *}$ \\
\hline & & $(0.000)$ & $(0.000)$ \\
\hline \multirow[t]{2}{*}{ Education } & 0.112 & -0.109 & 0.160 \\
\hline & $(0.570)$ & $(0.559)$ & $(0.466)$ \\
\hline \multirow[t]{2}{*}{ Health } & $-0.586^{\dagger}$ & -0.188 & $-0.355^{*}$ \\
\hline & $(0.061)$ & $(0.021)$ & $(0.032)$ \\
\hline \multirow[t]{2}{*}{ FDI } & - & $-1.61 \mathrm{E}-07^{\dagger}$ & - \\
\hline & & $(0.069)$ & \\
\hline \multirow[t]{2}{*}{ Openness } & - & -0.116 & - \\
\hline & & $(0.169)$ & \\
\hline \multirow[t]{2}{*}{ Population_65 } & & - & -0.087 \\
\hline & & & $(0.295)$ \\
\hline \multirow[t]{2}{*}{ Population_15 } & & - & -0.177 \\
\hline & & & $(0.814)$ \\
\hline \multirow[t]{2}{*}{ Population_urban } & & - & 0.016 \\
\hline & & & $(0.237)$ \\
\hline \multirow[t]{2}{*}{ Constant } & $0.586^{* *}(0.003)$ & $0.638^{* *}$ & 0.827 \\
\hline & & $(0.000)$ & $(0.600)$ \\
\hline \multicolumn{4}{|l|}{ Growth Equation: } \\
\hline \multirow[t]{2}{*}{ Education } & $1.449^{\dagger}$ & $1.568^{\dagger}$ & $1.401^{\dagger}$ \\
\hline & $(0.076)$ & $(0.079)$ & $(0.088)$ \\
\hline \multirow[t]{2}{*}{ Health } & 0.034 & -0.010 & 0.046 \\
\hline & $(0.962)$ & $(0.897)$ & $(0.948)$ \\
\hline \multirow[t]{2}{*}{ Capital } & $0.980^{* *}$ & $1.108^{* *}$ & $1.071^{* *}$ \\
\hline & $(0.006)$ & $(0.009)$ & $(0.011)$ \\
\hline
\end{tabular}




\begin{tabular}{|c|c|c|c|}
\hline \multirow[t]{2}{*}{ Labour } & $4.455^{* *}$ & $4.867^{* *}$ & $4.835^{* *}$ \\
\hline & $(0.000)$ & $(0.000)$ & $(0.000)$ \\
\hline \multirow[t]{2}{*}{ FDI } & - & 2.03E-07 & - \\
\hline & & $(0.641)$ & \\
\hline \multirow[t]{2}{*}{ Openness } & - & -0.289 & -0.204 \\
\hline & & $(0.594)$ & $(0.691)$ \\
\hline \multirow[t]{2}{*}{ Constant } & $0.192^{* *}$ & 0.055 & 0.141 \\
\hline & $(0.837)$ & $(0.954)$ & $(0.880)$ \\
\hline \multicolumn{4}{|c|}{ Model diagnostics } \\
\hline \multirow[t]{2}{*}{$X^{2}$} & 3.617 & 1.401 & 2.021 \\
\hline & $(0.164)$ & $(0.705)$ & $(0.588)$ \\
\hline RMSEA & 0.201 & 0.000 & 0.000 \\
\hline AIC & -460.516 & -98.389 & -560.701 \\
\hline $\mathrm{BIC}$ & -449.563 & -84.449 & -547.634 \\
\hline CFI & 0.988 & 1.000 & 1.000 \\
\hline TLI & 0.946 & 1.051 & 1.029 \\
\hline SRMR & 0.006 & 0.002 & 0.005 \\
\hline CD (i.e. $\mathrm{R}^{2}$ ) & 0.996 & 0.997 & 0.997 \\
\hline
\end{tabular}

$\overline{\mathrm{P} \text {-values are reported in parenthesis. }{ }^{\dagger}, \text {, and } * * \text { indicate significance at } 10 \%, 5 \% \text { and } 1 \% \text { level }}$ respectively

Table 3: Direct and Indirect Effects Based on Model 2

\begin{tabular}{llll}
\hline & Direct & Indirect & Total \\
\hline GINI Equation: & & & \\
\hline
\end{tabular}




\begin{tabular}{llll}
\hline GDP & $0.195(0.000)$ & - & $0.195(0.000)$ \\
Education & $-0.109(0.559)$ & $0.306(0.093)$ & $0.197(0.424)$ \\
Health & $-0.188(0.210)$ & $-0.020(0.897)$ & $-0.208(0.328)$ \\
FDI & $-1.61 \mathrm{E}-07(0.069)$ & $-3.97 \mathrm{E}-08$ & $-1.22 \mathrm{E}-07$ \\
Openness & $-0.116(0.169)$ & $-0.056(0.595)$ & $-0.173(0.216)$ \\
Capital & - & $0.216(0.018)$ & $0.216(0.018)$ \\
Labour & - & $0.950(0.001)$ & $0.950(0.001)$ \\
& & & \\
Growth Equation: & & & $1.568(0.079)$ \\
Education & $1.568(0.079)$ & - & $-0.010(0.897)$ \\
Health & $-0.010(0.897)$ & - & $1.108(0.009)$ \\
Capital & $1.108(0.009)$ & - & $4.867(0.000)$ \\
Labour & $4.867(0.000)$ & - & $2.03 \mathrm{E}-07(0.641)$ \\
FDI & $2.03 \mathrm{E}-07(0.641)$ & - & $-0.289(0.594)$ \\
Openness & $-0.289(0.594)$ & - & \\
\hline P-Values are & & & \\
\hline
\end{tabular}

$\mathrm{P}$-values are reported in parenthesis. 